\title{
INTERAKSIONAL SIMBOLIK AKTOR GOVERNANCE DALAM KEBIJAKAN PERTAMBANGAN DI HUTAN LINDUNG GUNUNG TUMPANG PITU BANYUWANGI
}

\author{
Muhamad Imron \\ imron.unira@gmail.com \\ Program Studi Ilmu Pemerintahan Fakultas Ekonomi dan Ilmu Sosial \\ Universitas Islam Raden Rahmat Malang
}

\begin{abstract}
Although it often is imaginary, in fact, still quite well-being can be packaged attractively in the extractive industry practices. Welfare as a result of mining operations is actually the result of though construction on the existing realities. Welfare often positioned or constructed as a symbol that can facilitate acceptance of a policy. Communication patterns constructed by political elites through welfare bids can shut other desires that may be veiled. Interaction between actors presented governance (State-Private Sector-Civil Society-MNC) on mining operations in the Mountain Protection Forest Mixed Pitu Banyuwangi shows us a form of political communication and propaganda loaded. Color and pattern mining policy is dominated by the preferences and communication ansih elite level. Sound Governance approach is expected to provide opportunities for the emergence of parallel patterns of interaction for all potential possessed by all actors. All actors must be able to stand on equal footing in the face of all the problems that inevitably arise in every operation of the mining industry, such as environmental damage to the ecosystem, social and cultural impact, until the achievement of the welfare of the local community. Welfare should ideally not be imaginary side of an extractive industry, it should be presented through the strategic role of all actors existing governance. The approach used in this study is qualitative wrapped with critical paradigm. This is done to strip to the deepest problems of the cases in the study. While policy analysis is done by using the approach of Walt and Gilson through the blades of analysis for the study of policy such as policy analysis model consisting of aspects of the content, context, process, and actor. While Palmer \& Short presents a number of relevant questions in a critical review of a policy. In this study, both approaches are combined and then reviewed again by the advocacy coalition framework as a form of triangulation methods of analysis. This study aims to reveal the form of political communication as well as see the symbolic interaksionalisme actor governance in the mining policy practices.
\end{abstract}

Keywords: Interaction between actors, mining policy, communication patterns

\begin{abstract}
Abstraksi
Meski seringkali bersifat imaginer, kesejahteraan nyatanya masih cukup dapat dikemas dengan menarik pada praktik industri ekstraktif. Kesejahteraan sebagai hasil dari operasi pertambangan sesungguhnya merupakan hasil dari olah konstruksi atas realitas yang ada. Kesejahteraan sering diposisikan atau bahkan dikonstruksikan sebagai simbol yang dapat mempermudah diterimanya suatu kebijakan. Pola komunikasi yang dibangun oleh para elit politik melalui tawaran kesejahteraan dapat menutup rapat keinginan lain yang mungkin terselubung. Interaksi yang tersaji antar aktor governance (State-Private Sector-Civil Society-MNC) pada operasi pertambangan di Hutan Lindung Gunung Tumpang Pitu Banyuwangi menunjukkan pada kita suatu bentuk komunikasi yang politis dan sarat propaganda. Warna dan corak kebijakan pertambangan lebih didominasi oleh preferensi dan komunikasi level elit ansih. Pendekatan Sound Governance diharapkan dapat memberikan peluang demi munculnya pola interaksi yang sejajar bagi seluruh potensi yang dimiliki oleh semua aktor. Seluruh aktor harus mampu berdiri secara sejajar dalam menghadapi segala persoalan yang pasti muncul pada setiap operasi industri pertambangan, seperti kerusakan ekosistem lingkungan, dampak sosial budaya, hingga tercapainya kesejahteraan masyarakat lokal. Kesejahteraan idealnya bukanlah menjadi sisi imaginer dari sebuah industri ekstraktif, ia harus dapat dihadirkan melalui peran strategis dari seluruh aktor governance yang ada. Pendekatan yang digunakan dalam penelitian ini
\end{abstract}


adalah kualitatif yang dibalut dengan paradigma kritis. Hal ini dilakukan untuk mengupas hingga masalah terdalam dari kasus dalam penelitian. Sedangkan analisis kebijakan dilakukan dengan menggunakan pendekatan Walt \& Gilson melalui pisau analisis untuk studi kebijakan berupa model analisis kebijakan yang terdiri atas aspek konten, konteks, proses, dan aktor. Sedangkan Palmer \& Short menyajikan sejumlah pertanyaan yang relevan dalam meninjau kritis suatu kebijakan. Dalam kajian ini, kedua pendekatan tersebut digabungkan dan kemudian ditinjau sekali lagi dengan kerangka koalisi advokasi sebagai bentuk triangulasi metode analisis. Penelitian ini bertujuan mengungkap bentuk komunikasi politik serta melihat interaksionalisme simbolik aktor governance dalam praktik kebijakan pertambangan.

Kata Kunci: Interaksi antar aktor, kebijakan pertambangan, pola komunikasi

\section{PENDAHULUAN}

Negara Indonesia terkenal memiliki beragam sumber daya alam, mulai dari pertanian, perikanan, perkebunan, hingga pertambangan. Fakta sejarah telah membuktikan tentang bagaimana berhasratnya bangsa Belanda kala itu untuk datang ke Indonesia demi memperoleh rempah-rempah hingga hasil bumi lainnya. Revolusi industri di Eropa, menjadi salah satu faktor pendorong bagi bangsa-bangsa Eropa melakukan ekpansi ke berbagai belahan dunia, termasuk Indonesia. Salah satu syarat untuk terus bergulirnya revolusi industri saat itu adalah tersedianya sumber daya alam yang siap untuk di produksi dalam jumlah besar, sedang sumber daya alam yang dimiliki oleh bangsabangsa Eropa tidak sebesar (jika di banding) dengan yang dimiliki oleh bangsa-bangsa di benua lainnya, termasuk asia. Dan bangsa Indonesia memang memiliki kekayaan alam yang (bagi bangsa barat) begitu menakjubkan jumlahnya. Hampir di seluruh penjuru negeri ini memiliki ragam kekayaan alam yang sesungguhnya berpotensi besar untuk mensejahterakan rakyat.
Dan sektor pertambangan merupakan salah satu sektor saja yang (jika di kelola dengan baik) niscaya dapat meningkatkan kesejahteraan rakyat. Indonesia merupakan penghasil utama beberapa mineral. Negara Indonesia adalah penghasil timah terbesar kedua di dunia, eksportir batu bara thermal terbesar ketiga di dunia, penghasil tembaga terbesar ketiga dan menduduki urutan kelima dan ketujuh untuk produsen nikel dan emas. Potensi tembaga terbesar Indonesia terdapat di Papua, potensi lain tersebar di jawa Barat, Sulawesi Utara dan Sulawesi Selatan. Sedangkan potensi emas nyatanya hampir terdapat di seluruh wilayah Indonesia seperti di Pulau Jawa, Kalimantan, Sumatra, Sulawesi, Nusa Tenggara, Kepulauan Riau, Maluku dan tentu saja Papua. Adapun potensi nikel terdapat di Sulawesi, Kalimantan Bagian Tenggara, Maluku dan Papua. Sementara timah berada di Pulau Bangka, Pulau Belitung, Pulau Singkep, Pulau Karimun. Kekayaan sumber daya alam yang melimpah ruah dari Sabang hingga Merauke, kekayaan alam yang tidak semua negara memilikinya. (Salamudin:2011). 
Data yang di miliki oleh Price Waterhouse Cooper menyatakan bahwa industri pertambangan di Indonesia telah menyumbang sekitar 4-5\% dari seluruh Produk Domestik Bruto Indonesia. Bagaimanapun, sektor industri pertambangan juga turut memiliki peran penting bagi beberapa provinsi yang kaya akan sumber daya mineral dan batu bara, antara lain Papua, Bangka Belitung, Nusa Tenggara, dan Kalimantan Timur. Walaupun sejak 2009 terjadi fluktuasi hasil produksi yang memiliki kecenderungan mengalami penurunan, bagi komoditas tembaga, emas dan nikel, tetapi penurunan tersebut lebih disebabkan faktor harga pasar atau aspek operasional (Price Waterhouse Cooper: 2012). Dan oleh karena sektor ini cukup menjanjikan kesejahteraan bagi rakyat, maka peran pemerintah menjadi sangat di butuhkan dalam mengatur eksploitasi sektor pertambangan tersebut.

Terdapat ketimpangan di dalam peran yang diambil pemerintah sejak orde baru yakni lebih memilih menjadi fasilitator bagi korporasi-korporasi besar internasional dari pada membuat tata kelola pertambangan yang baik. UU No. 11 Tahun 1967 tentang pertambangan umum yang begitu fenomenal telah menjadi karpet merah bagi investasi asing pada sektor ekstraktif di Indonesia. Mekanisme kontrak karya yang disediakan oleh undang-undang tersebut menjadikan relasi yang setara sama tinggi antara pihak pemerintah dengan pihak korporasi (Government to Business). Sehingga pola hubungan dan dinamika pertambangan hanya di tentukan oleh hasil main mata antara kedua aktor tersebut. Sistem kontrak karya juga begitu memungkinkan adanya relasi dominatif dari korporasi terhadap masyarakat.

Dan seiring dinamika pemikiran yang terus berkembang, terutama paska reformasi, UU No. 11 Tahun 1967 di anggap telah usang dan tidak sesuai lagi dengan pilihan politik ekonomi yang dijalankan pemerintah. Sehingga Undang-Undang tersebut diganti dengan Undang-Undang yang baru, yakni Undang-Undang No. 4 Tahun 2009 tentang Pertambangan Mineral dan Batubara (UU No. 4 Tahun 2009). Oleh banyak kalangan UU ini dianggap telah membuka babak baru wajah pertambangan di negara Indonesia, diantaranya terdapat ketentuan-ketentuan baru yang memang menunjukkan adanya pergeseran paradigma dalam pengelolaan sumber daya mineral dan batu bara. Misalnya saja, undang-undang ini berbicara tentang hubungan (interaksi) negara dan pihak pemodal (investasi asing). Sistem kontrak karya yang dahulu pernah diterapkan lama saat rejim orde baru kini telah di ubah dengan sistem Izin Usaha Pertambangan yang memiliki aturan durasi penggunaan lahan lebih singkat jika di banding undang-undang sebelumnya. Selain itu undang-undang baru ini juga menyajikan suatu sudut pandang divestasi saham investasi asing sebagai instrumen menegakkan kedaulatan ekonomi.

Perubahan dari sistem Kontrak Karya ke arah Izin Usaha Pertambangan ini merupakan perubahan kebijakan yang dilakukan oleh Dewan Perwakilan Rakyat 
(DPR) bersama pemerintah. Keduanya, memiliki perbedaan yang cukup mendasar. Menurut Spelt dan Ten Berge, izin merupakan sebuah tanda persetujuan dari pemerintah, berdasarkan peraturan perundang-undangan, bagi subyek hukum untuk dalam keadaan tertentu menyimpang dari ketentuan larangan peraturan perundang-undangan. Dengan memberi izin, berarti pemerintah memperkenankan orang yang mengajukan permohonan untuk melakukan tindakantindakan tertentu yang sebenarnya dilarang (NM Spelt:1993). Pada dasarnya pola perizinan semacam ini memberi kedudukan yang lebih tinggi (dominan) pada pemerintah kita, dan memberikan kedudukan yang lebih rendah pada perusahaan-perusahaan yang telah mengajukan permohonan izin. Tentu berbeda dengan pola kontrak karya, yang memberikan posisi sejajar antara pemerintah dengan korporasi (perusahaan pertambangan).

Namun, apakah praktiknya akan selalu demikian (pemerintah lebih dominan), karena telah banyak bukti pula, pemerintah kita selalu lemah menghadapi lobi-lobi dari korporasikorporasi besar pengelola tambang yang ada. Interaksi yang terbangun antara State-Multi National Corporation selalu terlihat mesra dan intim, sedangkan civil society lebih pada posisi (di) diam (kan) begitu saja. Tekanan yang sering muncul dari MNC/TNC kepada pihak pemerintah atas keberlanjutan aktivitas eksploitasi sumber daya mineral dan batu bara acapkali tidak dapat ditolak, bahkan pemerintah justru mengambil posisi sebagai penyedia regulasi yang lapang dan longgar bagi keberlangsungan pertambangan.

Dalam pola komunikasi politik, perlu melihat pula bentuk interaskionalisme simbolik. Hal ini perlu dilakukan sebab memiliki kaitan dengan pengambilan kebijakan dan aspek politik dalam birokrasi. Komunikasi yang dapat dilihat adalah dari interaksi simbol para aktor governance dalam mengambil kebijakan yang memiliki relevansi dengan kepentingan pengambil kebijakan dan pemilik modal.

Sesuai dengan konsep yang dikemukakan Blumer bahwa interaksi simbolik melekat pada tindakan politik. Sebab interaksionalisme simbolik memiliki perspektif bisa dimaknai melalui jalinan komunikasi yang menghasilkan makna dan dilakukan dalam interaksi sosial serta terdapat pengelolaan makna dan intepretasi untuk disampaikan kembali kepada lawan bicara (Snow, 2000: 367).

Nampaknya, kedepan, wajah pertambangan di negara kita akan masih tidak jauh berbeda selama pemerintah tidak dapat menciptakan suasana interaksi antar aktor yang seimbang. Misalnya, dalam kasus PT. Freeport Indonesia hingga kini masih simpang siur pemberitaan belum terbangunnya smelter. Menurut Undang-Undang No. 4 Tahun 2009 tentang Pertambangan Mineral dan Batubara, smelter harus dibangun paling lambat 5 tahun setelah UU tersebut disahkan. Dan kenapa pada Undang-Undang No. 4 Tahun 2009 tentang Pertambangan Mineral dan Batubara 
khususnya tentang Ketentuan Peralihan, pasal 169 berbunyi "Kontrak karya dan perjanjian karya pengusahaan pertambangan batubara yang telah ada sebelum berlakunya undangundang ini tetap di berlakukan sampai jangka waktu berakhirnya kontrak/perjanjian" ini menimbulkan kesan bahwa sistem kontrak karya dan perjanjian masih tetap dapat terlayani kepentingannya. Lantas dimana posisi sistem Izin Usaha Pertambangan (IUP) yang oleh banyak kalangan dianggap memiliki daya tawar kuat di depan para pelaku asing.

Kompleksnya masalah yang terjadi bisa dilihat dari aspek komunikasi politik yang terjadi. Sehingga dalam penelitian ini bermaksud mengungkap tentang bentuk komunikasi politik serta melihat interaksionalisme simbolik aktor governance dalam membuat kebijakan di kasus kegiatan pertambangan yang terjadi di hutan lindung Tumpang Pitu Banyuwangi.

\section{METODE PENELITIAN}

Kajian interaksional simbolik aktor governance dalam kebijakan pertambangan ini disajikan secara deskriptif berdasarkan studi yang ada. Pendekatan yang digunakan dalam penelitian ini adalah kualitatif yang dibalut dengan paradigma kritis. Hal ini dilakukan untuk mengupas hingga masalah terdalam dari kasus dalam penelitian. Sedangkan analisis kebijakan dilakukan dengan menggunakan pendekatan Walt \& Gilson melalui pisau analisis untuk studi kebijakan berupa model analisis kebijakan yang terdiri atas aspek konten, konteks, proses, dan aktor. (Walt
\&Gilson, 1994 :354) Sedangkan Palmer \& Short menyajikan sejumlah pertanyaan yang relevan dalam meninjau kritis suatu kebijakan. ( Palmer \& Short, 1998:370) Dalam kajian ini, kedua pendekatan tersebut digabungkan dan kemudian ditinjau sekali lagi dengan kerangka koalisi advokasi sebagai bentuk triangulasi metode analisis.

\section{HASIL DAN PEMBAHASAN}

\section{Aktor Governance dan Pembuatan Kebijakan}

Tiga aktor yang telah di utarakan dalam konsep Good Governance (StatePrivate Sector-Civil Society) nyatanya sudah tidak cukup relevan dalam memotret persoalan kekinian yang kian kompleks. Kini, ada satu lagi aktor yang tidak dapat di remehkan perannya dalam membangun ataupun meruntuhkan berbagai tatanan yang telah ada. Multi National Corporation, menjadi aktor baru (yang sesungguhnya telah lama ada) dalam kehidupan berbangsa dan bernegara kita. Aktivitas mereka seringkali tidak terpotret dengan baik oleh masyarakat atau bahkan pihak negara (state). Ekspansi mereka yang makin hari makin menggurita perlu untuk di waspadai, tentu karena tak jarang dalam urusan lobi-lobi, mereka acapkali membikin negara (state) kelimpungan dan kuwalahan. Untuk itu, perlu melihat persoalan pertambangan di negara kita dengan sebuah kaca mata baru, yang mampu memotret 4 aktor ini (State-Private Sector-Civil SocietyInternational Actor) dengan baik. Perlu 
konsepsi baru yang mampu menjawab kegamangan negara dalam merumuskan undang-undang agar hasilnya tidak selalu untuk melayani pihak asing semata. Sound Governance dengan analisis 4 aktornya di harapkan mampu menjelaskan dan mencari solusi atas persoalan yang kian rumit ini. Menunjukkan mana yang telah keliru dalam kebijakan pertambangan di negara kita, sekaligus memberikan tawaran reformasi kebijakan publik.

Di Banyuwangi, eksplorasi pertambangan mineral menghampiri sebuah hutan lindung yang berada di ujung selatan kabupaten tersebut. Secara tiba-tiba, Hutan Lindung Gunung Tumpang Pitu (HLGTP) tersebut beralih status menjadi hutan produksi. Merasa tidak dilibatkan, masyarakat menyatakan menolak. Derasnya aksi penolakan terhadap alih fungsi kawasan hutan lindung, nampaknya tidak mengubah pendirian dan hasrat pemerintah untuk terus mengobral kekayaan sumber daya alamnya. Buktinya, Kabupaten Banyuwangi justru menjadi target kebijakan pertambangan. Adalah PT Bumi Suksesindo (PT BSI) yang kini telah memperoleh izin usaha pertambangan hingga bulan Januari tahun 2030. Lewat surat keputusan Menteri Kehutanan bernomor SK 826/Menhut-II/2013 tertanggal 19 November 2013 Hutan Lindung Gunung Tumpang Pitu (HLGTP) telah resmi berubah status menjadi hutan produksi. PT BSI yang merupakan anak perusahaan dari Merdeka Copper Gold, perusahaan ini telah mencatatkan saham perdana di PT Bursa Efek Indonesia pada Juni
2015. Perusahaan yang berdiri pada 5 September 2012 ini bergerak di sektor pertambangan emas, perak, tembaga, dan mineral lainnya. Areal pertambangan yang dimiliki yakni di Desa Sumberagung, Kecamatan Pesanggaran, Kabupaten Banyuwangi, Jawa Timur. Tepatnya perseroan ini memiliki konsesi pertambangan di Tujuh Bukit atau Tumpang Pitu Banyuwangi.

Kini, melalui Peraturan Bupati Banyuwangi Nomor 26 Tahun 2012 Tentang Pelaksanaan Kegiatan Usaha Pertambangan Mineral Bukan Logam Dan/Atau Batuan Di Kabupaten Banyuwangi, operasi pertambangan di Hutan Lindung Gunung Tumpang Pitu Banyuwangi telah mulai dilakukan. Peraturan Bupati ini memberi peluang bagi perusahaan-perusahaan pertambangan untuk melancarkan operasi pertambangannya dengan begitu massif. Sayangnya, komunikasi dan keterlibatan aktor governance terlihat cukup kurang dalam peraturan yang ada tersebut. Ke depan, bisa jadi hal tersebut akan muncul sebagai persoalan atas tidak diberikannya peran yang baik bagi masyarakat yang sesungguhnya merupakan aktor utama governance.

Proyek Tujuh Bukit (Tumpang Pitu) tersebut berada dilahan seluas 4.998 hektare. Merdeka Copper Gold menguasai kawasan ini melalui dua anak usahanya, yakni PT Bumi Suksesindo dan PT Damai Suksesindo. Adapun perincian pemegang saham sebagai berikut: PT Trimitra Karya Jaya (14,59\%), PT Mitra Daya Mustika (14,59\%), Maya Miranda Ambarsari (8,05\%), Garibaldi Thohir (6,04\%), 
Pemda Kab Banyuwangi (5,68\%), PT Srivijaya Kapital (4,03\%), Andreas Reza Nazaruddin (2,01\%), Sakti Wahyu Trenggono (1,79\%), Pemegang MCB Willis (8,11\%), Pemegang MCB Emperor (11,45\%), Pemegang Opsi Emperor (1,99\%), masyarakat (21,68\%). (Web.merdeka copper gold). Berdasarkan peta kepemilikan saham tersebut diatas, maka setidaknya terdapat dua perusahaan asing (MCB Willis dan MCB Emperor) yang memiliki saham cukup signifikan. Sementara pemda Kabupaten Banyuwangi yang semula membidik kepemilikan saham hingga $10 \%$ ternyata hanya tercapai $5,68 \%$ saja. Peta kepemilikan saham ini semakin meniscayakan bahwa pola relasi antara negara-perusahaan nasional-multi national corporation-masyarakat akan berlangsung cukup ketat, dimana tidak hanya pihak swasta dalam negeri saja yang akan mencoba memberi warna pada kebijakan pertambangan di Banyuwangi, tetapi juga akan ada suara dari kepentingan pihak MNC atau perusahaan asing.

$\begin{array}{ccr}\text { Pola } & \text { komunikasi tersirat } \\ \text { interaksionalisme } & \text { simbolik yang terbangun }\end{array}$ antar aktor di atas begitu menarik untuk diteliti. Ini menjadi penting mengingat interaksi antar aktor (State-Market-Civil Society dan international actor) seringkali berlangsung dengan tidak seimbang. Terdapat aktor yang sengaja dilemahkan peranannya dalam memberikan warna pada sebuah kebijakan pertambangan, pada saat yang sama terdapat aktor-aktor yang dominan dalam mewarnai kebijakan pertambangan. Pada gilirannya aktor yang dilemahkan seringkali menjadi korban dari suatu kebijakan pertambangan yang elitis.

Interaksionalisme Simbolik dan Komunikasi Politik

Interaksionalisme simbolik didasarkan atas ide tentang individu dan interaksinya dengan masyarakat. Esensi interaksionalisme simbolik adalah suatu aktivitas yang merupakan ciri manusia yaitu komunikasi atau dengan kata lain pertukaran simbol yang sarat akan makna. Dalam perspektif ini menyarankan bahwa perilaku manusia dapat dilihat sebagai proses yang memungkinkan manusia membentuk dan mengatur perilaku mereka dengan mempertimbangkan ekspektasi lawan bicara yang menjadi mitra dalam interaksi. Definisi yang diberikan kepada orang lain, situasi, obyek dan bahkan diri mereka sendirilah yang menentukan perilaku manusia. Dalam konteks ini, maka dikonstruksikan dalam proses interaksi tersebut bukanlah suatu medium netral yang memungkinkan kekuatan-kekuatan sosial memainkan perannya, melainkan justru merupakan substansi sebenarnya dari organisasi sosial dan kekuatan sosial. (Mulyana, 2002 : 68-70)

Menurut Putnam dan Pacanowsky (1983), mereka meletakkan kerangka interaksionalisme simbolik dimana dapat diaplikasikan dalam komunikasi organisasi dan politik. Hal ini disebabkan organisasi dan politik merupakan sistem makna yang kompleks. Dasar dari interaksi adalah sistem 
makna yang dibuat oleh komunikator dan komunikan. Di dalam sebuah kelompok interaksi bisa terjadi dengan memahami situasi melalui pertukaran simbol. Simbol bisa dilakukan dalam interaksi negosiasi bahkan feedback dari sebuah komunikasi. Perilaku komunikasi yang menghasilkan interaksionalisme simbolis berdasarkan atas persepsi, penggunaan bahasa dan simbol, serta penyebaran makna yang sudah dibentuk sebelumnya. (Trevino, 1987 :555-556)

Kaitan interaksionalisme simbolik dengan komunikasi politik ada pada proses komunikasi yang bertumpu pada komunikator dan media yang digunakan. Dalam perkembangannya, komunikasi politik di negara dunia ketiga memiliki trend yang sering diistilahkan dengan chain of exogenous change. Tren tersebut meliputi: modernisasi, individualisasi, sekularisasi, pertumbuhan ekonomi, kecenderungan pemahaman tentang gaya hidup (Aestheticization), rasionalisasi, serta kondisi media. Banyak permasalahan pemerintah dipengaruhi oleh hal tersebut. Sehingga kontrol komunikasi politik tidak hanya terletak pada masyarakat namun aktor politik atau pelaku komunikasi politik saat ini dapat dilihat secara jelas dari pantauan media massa. Bahkan sebaliknya, konstruksi realitas dalam komunikasi politik memungkinkan terjadi melalui jalinan komunikasi yang berlangsung antara komunikator politik dengan media massa. (Blummer \& Kavanag ,1999: 210-211)

Senada dengan hal tersebut, Mazzoleni \& Schulz (2010) menjelaskan bahwa proses penggunaan media aktor politik dalam menciptakan peristiwa politik, dan wacana politik menjadi tren utama dalam sistem politik tahun 1990-an. Ini adalah fenomena yang menunjukkan kekuatan media dalam hal kecepatan ekspansi dan komersialisasi sistem media dalam modernisasi politik. Sehingga aktor politik bisa menciptakan interaksi simbolik yang terselubung menggunakan bantuan media. Seluruh tujuan politik bisa dicapai melalui konstruksi realitas dan masyarakat nyaris bisa memahami bahkan tidak ada penolakan atas propaganda aktor politik.

Nyatanya, aktor-aktor elit seperti perumus kebijakan (elit politik) dan pemodal selalu saja membungkus kebijakan pertambangannya dengan iming-iming kesejahteraan yang akan diterima oleh masyarakat. Kesejahteraan sesungguhnya adalah hasil dari olah konstruksi atas realitas yang ada. Kesejahteraan menjadi simbol yang mengantarkan/memudahkan agar masyarakat dapat dengan cepat menerima suatu kebijakan. Konstruksi kesejahteraan (yang diciptakan) sebagai efek positif atas digelarnya praktik industrialisasi di bidang ekstraktif menjadi alat penangkal atas aksi penolakan yang mungkin akan dilakukan oleh masyarakat. Para elit sesungguhnya telah mengerti bahwa industri ekstraktif seringkali mendapat penolakan dari warga sekitar area pertambangan, dan mereka akan banyak belajar dari situ. Melakukan pola komunikasi yang baik dengan masyarakat mungkin menjadi satu-satunya pilihan (selain dengan para perumus kebijakan). Pola 
komunikasi yang baik melalui tawaran kesejahteraan dapatlah menutupi secara rapat keinginan lain yang terselubung. Dalam praktik konstruksi atas realitas diatas, tidak jarang elit lokal di Banyuwangi sengaja menggunakan bantuan media massa. Pada era moderen seperti sekarang, media masih memiliki peran strategis sebagai alat propaganda realitas. Media dapat menyajikan beberapa gambaran elok dari praktik industri pertambangan. Menjalin kerjasama yang baik dengan media merupakan keniscayaan bagi kelompok elit.

\section{Tawaran Sound Governance}

Konsep Sound Governance di Indonesia terbilang masih relatif baru, bahkan belum banyak di kenal apalagi diterapkan. Meski belumlah dapat disebut matang, konsep ini nyatanya sarat dengan kritik yang merombak gagasan lama yakni Good Governance. Konsep ini muncul saat dunia, terutama negara-negara berkembang, tengah menikmati resep Good Governance yang di racik oleh UNDP (United Nation Development

Program). Saat pertama hadir, Good Governance menjelma layaknya obat mujarab yang pasti akan cocok bila diterapkan dalam tata pemerintahan, terutama bagi negara berkembang yang tengah menemui jalan terjal dalam berbagai sektor, ekonomi, kemiskinan, bisnis perusahaan, kelautan dan pengelolaan sumber daya alam termasuk pertambangan. Bagaimana tidak, konsep ini menawarkan banyak ramuan jitu dalam mengelola negara, semisal tentang perlunya di bangun budaya transparansi pada lembaga-lembaga pemerintahan, serta distribusi anggaran pemerintah dan pihak bisnis (private) kepada masyarakat miskin merupakan sekelumit contoh gagasan Goood Governance yang terlihat menarik.

Pada negara berkembang, konsep good governance ini seolah-olah telah menjadi kesepakatan bersama untuk menggunakannya demi tata pemerintahan yang lebih baik. Pola hubungan yang ditawarkan antar tiga aktor pun juga sangat menarik, dengan penempatan posisi yang sama antara state-market-civil society. Pola hubungan semacam ini di anggap akan membawa dampak positif bagi kesejahteraan masyarakat, karena sektor swasta di anggap bakal dapat menjalin hubungan atau komunikasi yang baik dengan negara, bahkan dengan masyarakat. Namun, kritik terhadap konsep yang dianggap telah matang ini rupanya tetap tidak bisa dibendung. Adalah Ali Farazmand yang mengutarakan bahwa konsep good governance telah lalai memasukkan arus globalisasi yang kini berjalan begitu massif dalam kerangka analisisnya. Sekali lagi, dalam good governance seolah-olah berjalannya kehidupan berbangsa dan bernegara ini hanya menyangkut interaksi antara negara, sektor swasta dan rakyat saja. Padahal, ada aktor lain yang perlu sekali untuk diperhitungkan, yakni dunia internasional. Oleh ia, aktor internasional ini bisa WTO, IMF, United Nation, bahkan hingga Multi National Corporation/MNC. Realitas global yang tengah berlangsung saat ini sungguh tidak dapat dipungkiri, mereka memainkan peran 
dengan sangat rapi baik dengan dampak positif atau pun dampak negatif yang mereka bawa ke negara-negara berkembang. IMF misalnya, rajin sekali menawarkan pinjaman ke negaranegara berpotensi krisis. Atau bahkan MNC yang telah menggurita ke banyak sekali negara-negara di dunia ini. Dan PT Freeport Mc Mooran adalah contoh nyata begitu perkasanya kekuatan mereka dalam memainkan orkestra kehidupan ini. Sejak tahun 1967 perusahaan ini telah resmi menancapkan bendera perusahannya di bumi Indonesia. Melalui kedekatannya dengan rejim saat itu, mereka telah di duga memesan berbagai regulasi agar posisi mereka tetap dapat kokoh berdiri di tanah Papua. Undangundang Penanaman Modal Asing adalah contoh kongkrit tentang bagaimana mereka dapat bertahan hingga sekarang dengan izin kontrak karyanya.

Jika kita amati dengan cermat, relasi yang dibangun antara negara, pihak swasta dan rakyat ternyata tak cukup dapat mendongkrak kekuatan ekonomi rakyat. Buktinya, beberapa kali Indonesia masih saja terdampak krisis ekonomi yang secara langsung berimbas pada rakyat. Dari sini, sesungguhnya ada yang keliru dari kita, karena krisis ekonomi nyatanya menyangkut konstalasi global yang meniscayakan hubungan antar negara dalam dunia. Ada hal yang kurang dapat kita antisipasi, yakni pengaruh aktor internasional.

\section{Sound Governance dan Pola Baru Interaksi antar Aktor}

Ali Farazmand menawarkan konsep baru, bernama Sound Governance. Gagasan ini muncul karena di ilhami oleh seorang Presiden Tanzania, Julius K. Nyerere, yang dalam konferensi PBB tahun 1998 melontarkan kritik pedasnya, bahwa good governance adalah konsep imperialis dan kolonialis. Good governance, kata dia, dapat mengerdilkan struktur negara berkembang, dan pada saat yang sama kekuatan bisnis internasional semakin membesar dan tak terbendung. Kritik ini tentu tidak bisa dianggap sebagai suara angin yang mudah berlalu begitu saja, melainkan harus disikapi dengan bijak, bahwa nyatanya konsep good governance yang oleh banyak orang dianggap bakal implementatif dan tepat untuk diterapkan ke birokrasibirokrasi di negara mereka belumlah tentu. Permainan aktor internasional menjadi tidak terdeteksi dengan baik oleh karena bangunan kesadaran kita hanya tertuju pada tiga aktor yang ada. Mengguritanya bisnis Multi National Corporation (MNC) pada negaranegara berkembang semakin menjadi dan sulit terbendung, negara semakin bisa di ajak kompromi oleh pihak MNC dengan imingiming bagi hasil keuntungan atas kehadiran mereka di negara tersebut. Hingga "main mata" antara state dan MNC pun tak dapat terhindarkan. Melalui lobi-lobi kuat dari pihak MNC acapkali dapat mempengaruhi negara untuk menjadi pelayannya, atau fasilitator mereka agar membuat regulasi-regulasi yang dapat mendukung keberadaan dan aktivitas produksi mereka pada negara-negara tersebut. Pada saatnya, kebijakan publik yang dibuat, tak ubahnya demi melayani kerakusan MNC. 
Dan Sound Governance memiliki perhatian pada persoalan-persoalan ini. Bagi ia, sebaik apapun pemerintahan lokal, bila struktur yang terbangun pada tingkat global tetap tidak adil, maka untuk mencapai kesejahteraan masyarakat adalah sulit. Sound governance yang di usung oleh Ali Farazmand ini mempunyai formulasi dasar, yakni 4 aktor dan 5 komponan. Empat aktor inilah yang akan digadang-gadang dapat membangun pola hubungan yang penuh dengan keterbukaan antara negara, masyarakat, dan kekuatan internasional. Adapun yang termasuk dalam kekuatan internasional ini adalah organisasiorganisasi internasional, perjanjian internasional hingga perusahaan-perusahaan (corporations) besar kelas dunia. Lima komponen adalah mencakup reformasi struktur, proses, nilai, kebijakan dan manajemen. Perlu diketahui, kata "Sound" ini memiliki arti ideal (Farazmand: 2004). Berarti, pemerintahan yang ideal, suatu pemerintahan yang mampu menggagas sebuah konstruksi ideal bagi hubungan (interaksi) antara empat aktor diatas.

\section{Sound Governance Memotret Realitas Industri Ekstraktif}

Untuk mendeskripsikan realitas kebijakan pertambangan di Hutan Lindung Gunung Tumpang Pitu Banyuwangi, nampaknya pendekatan Sound Governance ini akan dapat memotret dengan lebih komprehensif, karena aktor-aktor yang sedang berinteraksi di lapangan juga menyebutkan adanya aktor/perusahaan internasional (international corporation). Adalah MCB
Emperor dan MCB Willis yang meskipun secara kepemilikan saham masih di bawah perusahaan nasional lainnya, mereka berdua masih cukup memiliki kekuatan untuk turut memainkan kebijakan pertambangan di Banyuwangi. Secara kesejarahan, Perusahaan Willis ini sejak tahun 2006 sebenarnya telah melakukan eksplorasi emas di hutan tersebut namun karena terdapat konflik internal dalam lingkaran perusahaan-perusahaan rekanannya maka mengakibatkan dia harus melepas sahamnya yang semula $74 \%$ menjadi hanya 8,11\% saja. Selain itu UU No. 14 tahun 2009 juga tidak memperbolehkan kepemilikan saham perusahaan asing melebih $51 \%$. Hasil negosiasi selanjutnya adalah perusahaan asing ini harus menurunkan kepemilikan sahamnya namun masih tetap dapat menanamkan sahamnya meski tidak sebanyak dulu.

Sementara itu, Pemerintah Daerah Banyuwangi yang awalnya memaksa agar memperoleh saham sebesar $10 \%$, nyatanya ketika IPO di gelar di bursa saham hanya mampu mendapatkan 5,68\% saja. Kepemilikan saham yang hanya sedikit dan di bawah kepemilikan perusahan-perusahaan asing semacam ini juga rentan, paling tidak bergaining position dalam menentukan arah kebijakan akan dapat terpengaruhi oleh aktoraktor lainnya.

Dan pendekatan Sound Governance memberikan peluang untuk mensejajarkan seluruh potensi yang dimiliki oleh aktor-aktor yang ada. Negara, masyarakat, sektor swasta, hingga perusahaan asing harus mampu dan mau untuk duduk bersama melihat persoalan- 
persoalan yang selalu muncul pada setiap aktivitas pertambangan, seperti kerusakan lingkungan, dampak sosial budaya, kesejahteraan masyarakat lokal. Setidaknya Lima komponen sound governance mencakup reformasi struktur, proses, nilai, kebijakan dan manajemen haruslah dapat tercapai dengan baik.

Situasi akan berbeda jika hanya akan menggunakan pendekatan good governance, bagaimanapun, pendekatan ini hanya menyajikan 3 aktor saja (tanpa international corporations). Yang kemudian dapat terpotret hanyalah interaksi antar negara, masyarakat, dan sektor swasta atau perusahaan nasional saja. Peran korporasi internasional tidak dapat terdeskripsikan dengan baik, karena alat bantu yang memang tidak cukup memadai untuk mengamatinya. Pada kasus-kasus pertambangan di kawasan lainnya, semacam di Papua dengan PT Freeport Indonesia, perusahaan ini terbukti telah melakukan persekongkolan dengan pemerintah pusat dan daerah untuk terus melanggengkan aktivitas industrinya meski kesalahan-kesalahan masih berulangkali tetap dilakukan, misalnya smelter yang belum terbangun, tailing yang masih mengalir ke sungai-sungai setempat, pembagian prosentase yang relatif belum adil hingga persoalan-persoalan sosial budaya yang masih berlangsung hingga saat ini.

\section{PENUTUP}

\section{Simpulan Dan Saran}

Interaksi antar aktor governance (State-Private Sector-Civil Society-MNC) pada kebijakan pertambangan di Hutan Lindung Gunung Tumpang Pitu Banyuwangi menunjukkan bentuk komunikasi yang politis dan sarat propaganda. Komunikasi level elit sesungguhnya lebih memberikan warna pada implementasi kebijakan tersebut. Komunikasi level elit ini di dominasi oleh aktor politik, perusahaan pemegang ijin, dan pihak perusahaan asing (MNC). Mereka secara indah mengemas kebijakan pertambangan dengan wajah yang ramah dan pro kepada kepentingan masyarakat. Kesejahteraan menjadi imingiming positif dari relasi yang mereka jalin dengan masyarakat. Kesejahteraan menjadi hasil konstruksi atas realitas yang ada. Kesejahteraan menjadi simbol yang di desain menarik agar masyarakat dapat dengan mudah menerima hadirnya operasi pertambangan. Konstruksi kesejahteraan diharapkan dapat meredam berbagai aksi penolakan yang bisa saja muncul dari pihak masyarakat.

\section{Pendekatan Sound Governance} memberikan peluang untuk pola interaksi yang sejajar bagi seluruh potensi yang dimiliki oleh semua aktor. State (elit politik), Private Sector (pelaku usaha/perusahaan nasional), Civil Society (masyarakat) dan Multi National Corporation (aktor/perusahaan internasional) harus mampu dan bersedia untuk berposisi sejajar melihat persoalan-persoalan yang sering muncul pada setiap operasi pertambangan, seperti kerusakan lingkungan, dampak sosial budaya, hingga kesejahteraan masyarakat lokal. Kesejahteraan idealnya bukanlah menjadi sisi imaginer dari sebuah praktek pertambangan, ia harus dapat 
diwujudkan melalui peran dari seluruh stakeholder atau aktor governance yang ada. Seluruh aktor governance perlu sadar diri bahwa pembangunan haruslah selalu memperhatikan sisi kelestarian lingkungan. Pemerintah Daerah Banyuwangi haruslah memiliki keberpihakan yang jelas dan barang tentu tidaklah etis bila mereka hanya mengakomodir kepentingan rakusnya sektor industrialisasi di bidang ekstraktif.

\section{REFERENSI}

Blumler, Jay G., Kavanagh, Dennis. 1999. The Third Age of Political Communication: Influences and Features. Political Communication. Diakses di http://dx.doi.org/10.1080/105846099 198596 pada 12 Juli 2016.

Demmers, Jolle., at al (ed), 2004, Good Governance in the era of Global neoliberalism. London and New York: Routledge Taylor \& Francis Group.

Farazmand A., 2004, Sound Governance in the age of globalization. "Sound Governance: policy and administrative innovations: Wetsport praeger

Mazzoleni, $\quad$ Gianpietro., Schulz, Winfried.2010. "Mediatization" of Politics: A Challenge for Democracy? Political Communication. Diakses di http://dx.doi.org/10.1080/105846099 198613 pada 12 Juli 2016

Mulyana, Dedi. 2002. Metode Penelitian Kualitatif. Bandung : Rosdakarya

N.M.Spelt dan J.J.J.M. ten Berge, 1993, Pengantar Hukum Perijinan, disunting oleh Philipus Hadjon. Surabaya.

Pierre, Jhon (ed), 2000, Debating Governance. New York, USA: Oxford University Press Inc.

Price Waterhouse Cooper, 2012, Mining in Indonesia: investment and taxation guide.. www.pwc.com/id
Salamudin. 2009. Penjajahan Dari Lubang Tambang (Temali Modal Asing, Utang dan Pengerukan Kekayaan Tambang di Indonesia.. Malang: Jaringan Advokasi Tambang dan InTrans Publishing.

Snow, David A. 2001. Extanding and Broadening Blumer's Conseptualization of Symbolic Interactionism. Symbolic Interaction, Volume 24, Number 3, University of California Press.

Trevino, Linda Klebe., Lengel, Robert H., \& Daft, Ricchard L. 1987. Media Symbolism, Media Richness, And Media Choise in Organizations. A Symbolic Interactionist Perspective. Communication Research Vol. 14 No. 5, October 1987. Sage Publication, Inc.

Walt G, Gilson L. Reforming the health sector in developing countries: The central role of policy analysis. J. Health Policy Plann. 1994; 9 (4): Palmer GR, Short SD. Health Care and Public Policy, an Australian Analysis, 2nd ed. Melbourne:MacMillan Education Australia, 1998. 
Muhamad Imron, Interaksional simbolik aktor governance dalam kebijakan pertambangan di hutan lindung gunung tumpang pitu banyuwangi 